\title{
EVALUATION OF THE POSSIBILITY OF USING NANOCRYSTALLINE APATITE POWDERS AS INORGANIC FILLERS OF TOOTHPASTES
}

\section{S. KRIVILEVA}

\author{
department of "Chemical Technics and Industrial Ecology” NTU "KhPI”, Kharkiv, UKRAINE \\ email: spkri@ukr.net
}

\begin{abstract}
The article describes the most common types of toothpastes and materials used as inorganic abrasive polishing fillers therapeutic toothpastes available on the market. The prospects of using in the composition of therapeutic toothpastes and dentifrices for the teeth and mouth cavity of powders based on hydroxyapatite are evaluated. It is shown that in the products available on the market used biogenic hydroxyapatite submitted either in an inactive form, or containing deproteinized bone fish or farm animals (pigs or cattle). The prospects for the use of synthetic nanocrystalline apatite powder, purposefully developed for the plasticity of skeletal defects, in the composition of toothpastes and in dentifrice products - to replace inorganic components in their composition, consisting of chalk, kaolin, soda (in the lower price segment), is shown. titanium dioxide or aerosil (in the upper price range), or biogenic hydroxylapatite (as part of innovative premium products), traditionally used as abrasive components. It has been shown that synthetic nanocrystalline powders of $\mathrm{Ca}_{10}\left(\mathrm{PO}_{4}\right)_{6}(\mathrm{OH})_{2}$ can be obtained by the methods of "green chemistry" from solutions of $\mathrm{Ca}(\mathrm{OH})_{2}$ and $\mathrm{H}_{3}\left(\mathrm{PO}_{4}\right)_{2}$ grades of "chemically pure" and "analytically pure" (not containing heavy metals and ingredients of animal origin) and $\mathrm{Ca} a_{10}\left(\mathrm{PO}_{4}\right)_{6} \mathrm{~F}_{2}$ in the solid phase or by coprecipitation from solutions of $\mathrm{Ca}_{10}\left(\mathrm{NO}_{3}\right)_{2} \cdot 4 \mathrm{H}_{2} \mathrm{O}, \mathrm{NH}_{4} \mathrm{~F}$ and $\left(\mathrm{NH}_{4}\right)_{2} \mathrm{HPO}_{4}$ taken in the required stoichiometry, followed by heat treatment and grinding. The optimal ratios of the initial components and heat treatment regimes are determined, which ensure the production of $\mathrm{Ca}_{10}\left(\mathrm{PO}_{4}\right)_{6}(\mathrm{OH})_{2}$ powder with the ratio $\mathrm{Ca} / \mathrm{P}=1.67$ and $\mathrm{Ca}_{10}\left(\mathrm{PO}_{4}\right)_{6} \mathrm{~F}_{2}$ of high purity, whose crystal sizes correspond to the nanoscale range. When carrying out a full complex of toxicological and hygienic tests in vivo, it was established that the obtained material belongs to low-toxic, low-hazard substances with poorly expressed cumulative properties; it does not irritate the mucous membranes and does not possess gonadotoxic, embryotoxic, cytotoxic, mutagenic, teratogenic effects when ingested, which makes it safe and potentially promising to use it as an inorganic filler of toothpastes and agents for healing tooth enamel detection, $\mathrm{Ca}$ and $\mathrm{P}$ in it and restore the structure of the gingival mucosa.
\end{abstract}

Keywords: therapeutic toothpastes; dentifrices; abrasive-polishing fillers; hydroxylapatite; titanium dioxide

\section{ОЦНКА МОЖЛИВОСТІ ВИКОРИСТАННЯ НАНОКРИСТАЛІЧНИХ ПОРОШКІВ АПАТИТОВОГО СКЛАДУ В ЯКОСТІ НЕОРГАНІЧНИХ НАПОВНЮВАЧІВ ЗУБНИХ ПАСТ}

\section{С. П. КРИВІЛЬОВА}

кафедра хімічної техніки і промислової екології, НТУ «ХПІ», м. Харків, УКРАЇНА

\begin{abstract}
АНОТАЦІЯ У статті розглянуті найбільш поширені види зубних паст і матеріали, шо використовуються в якості неорганічних абразивних наповнювачів в існуючих на ринку лікувальних зубних пастах. Оиінена перспективність використання в складі лікувальних зубних паст $і$ засобів по догляду за зубами $і$ порожниною рота порошків на основі гідроксилапатиту. Показано, що в наявних на ринку продуктах застосовується біогенний гідроксилапатит, представлений або в неактивній формі, або у вигляді депротеінізованих кісток сільськогосподарських тварин (свиней або великої рогатоі худоби). Показана перспективність застосування синтетичних нанокристалічних порошків апатитового складу, цілеспрямовано розроблених для пластики дефектів скелета, в складі зубних паст і в продуктах по догляду за зубами - для заміни неорганічних компонентів в їх складі, щио складаються з крейди, каоліна, соди (у нижньому иіновому сегменті), діоксиду титану або аеросілу (у верхньому ичіновому сегменті), або біогенного гідроксилапатиту (у складі інноваційних продуктів преміум-класу), які традиційно використовуються у якості абразивних складових. Показано щцо екологічно чисті (що не містять важскх металів $i$ інгредієнтів тваринного походження) синтетичні нанокристалічні порошки $\mathrm{Ca}_{10}\left(\mathrm{PO}_{4}\right)_{6}(\mathrm{OH})_{2}$ можуть бути отримані методами «зеленої хімії» з розчинів $\mathrm{Ca}_{10}\left(\mathrm{PO}_{4}\right)_{6}(\mathrm{OH})_{2}$, a $\mathrm{Ca}_{10}\left(\mathrm{PO}_{4}\right)_{6} \mathrm{~F}_{2}-y$ твердій фазі або соосадженням з розчинів $\mathrm{Ca} 10\left(\mathrm{NO}_{3}\right)_{2} \cdot 4 \mathrm{H}_{2} \mathrm{O}, \mathrm{NH}_{4} \mathrm{~F}$ и $\left(\mathrm{NH}_{4}\right)_{2} \mathrm{HPO}_{4}$, взятих у необхідній стехіометрії, 3 наступною термообробкою і подрібненням. Визначено оптимальні співвідношення вихідних компонентів і режими термообробки, які забезпечують отримання порошку $\mathrm{Ca}_{10}\left(\mathrm{PO}_{4}\right)_{6}(\mathrm{OH})_{2}$ з співвідношенням $\mathrm{Ca} / \mathrm{P}=1,67$ і $\mathrm{Ca} 10\left(\mathrm{PO}_{4}\right)_{6} \mathrm{~F}_{2}$ високої чистоти з розміром кристалів у нанорозмірному діапазону. При проведенні повного комплексу токсиколого-гігієнічних випробувань іп vivo установлено, що отриманий матеріал відносяться до малотоксичних, малонебезпечних речовин зі слабо вираженими кумулятивними властивостями; він не подразнює слизові оболонки і не визиває гонадотоксичного, ембріотоксичного, иитотоксичного, мутагенного, тератогенного ефектів при потраплянні всередину організму, що робить перспективним $i$ безпечним його використання у якості неорганічного наповнювача зубних паст і засобів для заліковування детектів зубноі емалі, відновлення дефіцита Са и Р у ній.
\end{abstract}

Ключові слова: лікувальні зубні пасти; засоби по догляду за зубами; абразивно-поліруючі наповнювачі; гідроксилапатит; діоксид титану.

\section{Introduction}

In recent years, there has been a trend towards the use of innovative technologies and modern functional materials developed for reconstructive surgery, as part of special means intended for dental and oral care [1 - 4], as well as in the food industry and as food additives for special purposes. The problem of improving the population 
of the entire post-Soviet space is directly related to the elimination of a deficiency of calcium and phosphorus ions in the body. Currently, the population of virtually all countries of the former USSR, including Ukraine, and the post-Soviet Asian republics, is experiencing an acute shortage of calcium and phosphorus, which normally should come with food or with dietary supplements containing $\mathrm{Ca}$ and $\mathrm{R}$. Calcium deficiency in the territory post-Soviet states leads to the fact that annually more than 1 million people fall ill with diseases associated with its lack. Over the past 17 years (since 2000), the total number of cases has exceeded 35 million people. The most catastrophic state of affairs in Russia: it now has $75 \%$ of children suffering from osteopenia and $49 \%$ of children with osteoporosis; and the total number of adults suffering from osteoporosis exceeded 11 million. No less serious is the situation in Ukraine: we have about 7 million people (every 4-th woman over the age of 60) suffering from osteoporosis. The situation will worsen: according to estimates of the International Osteoporosis Foundation, by the year 2050 , more than $50 \%$ of the population of Ukraine over the age of 50 will suffer from this disease. The situation with osteoporosis is also aggravated by a shortage in the body of $75 \%$ of Ukraine's adult population of vitamin $\mathrm{D}$. This is also associated with malnutrition and a lack of stay in the sun, especially the older generation.

In addition to the deficiency of $\mathrm{Ca}$ and $\mathrm{P}$ on the condition of the osteoarticular system of the population of the countries of the former USSR, fluoride in the drinking water of certain regions also has an insufficient content. So, in Ukraine, the content of fluorine in drinking water (depending on the geochemical region) varies widely (from 0 to $3.0 \mathrm{mg} / \mathrm{l}$ at a rate of $0.7-1.2 \mathrm{mg} / \mathrm{l}$ ). Zero fluorine content is characteristic for a number of regions of Western Ukraine, a lower content for the Odessa region and the Crimea. Dentists fix a catastrophically high level of caries and periodontitis in the population of these areas. At the same time, in Central Ukraine and partly in the East everything corresponds to the norm. In the European countries and the USA this problem is solved by the appointment of tableted fluorine (it is prescribed even to pregnant women) and fluoridated water. But on the territory of the entire post-Soviet space, water has never been fluoridated. In this regard, a significant proportion of the population except osteoporosis is prone to tooth decay and suffers from premature tooth loss.

Today, the attitude to fluoride in the world is ambiguous. But his role in the prevention of tooth decay is undeniable. Therefore, in regions where the fluoride content in drinking water is not sufficient, the use of toothpastes with fluoride is advisable.

More recently, there have been widespread "family" toothpastes. They were hygienic and were intended only for mechanical removal of plaque on the teeth in order to eliminate chelitosis - bad breath. But since absolutely healthy teeth have less than $1 \%$ of the adult population of the post-Soviet space, today such pastes are used extremely rarely and are practically not produced.
By itself, brushing your teeth is not a preventive measure. To solve specific problems in the composition of pastes lead special ingredients. Each ingredient is designed to solve a particular problem. Toothpastes have become highly specialized: to strengthen tooth enamel, to combat periodontal pathology, to remove symptoms of hypersensitivity, bleaching, children, etc.

Today, all therapeutic and preventive tooth pastes are divided into:

- anti-inflammatory (with extracts of leukemia

plants: Parodontax, Lacalut Active, etc.);

- anti-caries (containing $\mathrm{Ca}^{2+}$ and $\mathrm{F}^{-}$: Blend-a-med

Komplit 7, Lacalut Fluor, etc.);

- bleaching (containing as an abrasive baking soda $\mathrm{NaHCO}_{3}$ : Lacalut White);

- for sensitive teeth with desensitizers (Parodontax);

- salt (stimulating blood circulation due to the content of mineral salts in its composition, which contribute to the intensification of metabolic processes in the gum, are effective for periodontitis and periodontitis, for example, Pomorin);

- therapeutic, for example, LOVE SPLAT Special

paste, which protects against a simple herpes virus;

- baby (which should not contain phosphate).

In addition to abrasives, various oils (pink petals or nutmeg), sweeteners (imitating, for example, the taste of marshmallow, or tropical fruits), foaming agents are introduced into the paste composition, and enzymes and bleaches are also used in clarifying pastes.

Abrasive-polishing agents account for up to $40 \%$ of the paste volume. Abrasives are powders that purify the tooth enamel from hard dental deposits and plaque [5]. The polishing agent is designed to remove plaque and food debris, forming bacteria colonies from the surface of the teeth. Abrasiveness of toothpaste is the abrasive effect of toothpaste and at the same time the degree of cleansing of the tooth surface from plaque. The degree of abrasiveness is determined not only by the quantity, but also by the quality of the abrasive. The larger the particle size, the more abrasive the toothpaste has. The smaller the particle size, the lower its abrasiveness. The abrasiveness of toothpastes is measured either by profilometry or by determining the "RDA" (Radioactive Dentin Abrasivity). This method was adopted by the American Association of Dentists [6]. It consists in the treatment of tooth paste, the dentin of which is processed by radioactive radiation. After cleaning the tooth, a slurry is formed containing the erased radioactive particles. The more of them, are higher than RDA. But there is no direct correlation between abrasiveness and wear resistance of enamel, as wear depends on a huge number of factors. Differences in the use of pastes with RDA 90 and RDA 204 have not been identified [7]. There are even paradoxical phenomena: for example, the soft toothbrush

of a toothbrush is larger and wears out enamel more quickly than hard enamel [8] regardless of the paste used. According to the ISO standard [9], toothpastes with an RDA $<250$ are considered safe for human use throughout 
life. But to date, there have not been recorded any tooth examinations due to abrasion and any other pastes.

In toothpastes of the lowest price category chalk, finely ground mollusk shells, eggshells or white clay (kaolin) are used as abrasives. The main minerals of the abrasives are $\mathrm{CaCO}_{3}$ or kaolinite $\mathrm{Al}_{2} \mathrm{O}_{3} \cdot 2 \mathrm{SiO}_{2} \cdot 2 \mathrm{H}_{2} \mathrm{O}$. Silicon dioxide $\mathrm{SiO}_{2}$ (aerosil) and $\mathrm{K}_{4} \mathrm{P}_{2} \mathrm{O}_{7}$ are used in the technology of manufacturing toothpastes of the highest price category. But since pastes based on them are expensive, small producers still use chalk and soda $\left(\mathrm{NaHCO}_{3}\right)$. Today, in the technology of manufacturing toothpastes, the most effective substance is titanium dioxide $\mathrm{TiO}_{2}$, giving them a white color. Pastes on its basis are the most expensive. In medium price toothpastes aluminosilicates and dicalcium phosphate $\mathrm{CaHPO}_{4} \cdot 2 \mathrm{H}_{2} \mathrm{O}$ are used as abrasives. In clarifying toothpastes, in addition to abrasives, bromelain or papain (enzymes) and bleaching components (carbamide peroxide, active oxygen [10]) are introduced.

The Ukrainian market for oral care products is very hot: the majority of the population uses toothpaste daily. A segment of therapeutic toothpastes is the most promising. Today it is inundated with the products of production of China, Turkey, the USA, Germany and other countries of the European Union. The products of Ukrainian producers are presented mainly in the lowest price category (price range from 12 to $130 \mathrm{UAH}$ per tube of $200 \mathrm{~g}$ ). As an abrasive filler, it uses white clay (TM "Ecolux"), chalk $\left(\mathrm{CaCO}_{3}\right.$, "Dentogin"), aerosil ( $\mathrm{SiO}_{2}, \mathrm{TM}$ "Ecolux"). As compounds of phosphorus pyrophosphates or fluorine salts are used (TPO "Image" of the Bogomolets Medicine University). The use of eggshells (as a source of $\mathrm{CaCO}_{3}$ ) in mass production is hampered by the absence of melange production facilities in the entire post-Soviet space that could provide the required amount of raw materials. And eggshells available on poultry-incubators, firstly, do not wash, and secondly, it is polluted by the presence of dead unhatched chicks, which makes it completely unsuitable for use in the production of toothpastes. The existing small amounts of waste products of the confectionery shops are not of industrial importance.

In the market of dental and oral care products, the segment of the means for healing tooth enamel detectors, replenishing the deficiency of $\mathrm{Ca}$ and $\mathrm{P}$ in it, or restoring the structure of the gingival mucosa is not filled. And this despite the significant spread of such damage among the population. Disks or special "pencils" for these purposes with a binder, for example, based on wax, etc., are not available on the market.

\section{Formulation of the problem}

Recently, the use of biogenic hydroxylapatite $\mathrm{Ca}_{10}\left(\mathrm{PO}_{4}\right)_{6}(\mathrm{OH})_{2}$ as an abrasive-polishing component of toothpastes began. Hydroxylapatite is more expensive today than fluorides, therefore in products for the mass market it is found only or in the form of more accessible and practically ineffective derivatives or in the form of ingredients of animal origin (de-proteinized bones of pigs or cattle or sea fish ridges). The use of raw materials of animal origin as a source of biogenic $\mathrm{Ca}_{10}\left(\mathrm{PO}_{4}\right)_{6}(\mathrm{OH})_{2}$ is ambiguous because of the possible introduction of various types of infections with animal protein. An ecologically clean and practically safe option is the use of hydroxyapatite, obtained from sea coral by hydrothermal treatment, but this source of raw materials is inaccessible due to limited production volumes.

In this regard, it seems promising to use environmentally friendly synthetic calcium phosphate materials of apatite composition. $\mathrm{Ca}_{10}\left(\mathrm{PO}_{4}\right)_{6}(\mathrm{OH})_{2}$, is a promising material for the healing of tooth enamel detectors and replenishment of the deficiency of $\mathrm{Ca}$ and $\mathrm{P}$, improvement of periodontal structure and for use as an abrasive component of new generation toothpastes. It is not something foreign to the body: both he and his metabolites are always present in the body. It is also characterized by high biocompatibility with living tissues [11]. $\mathrm{Ca}_{10}\left(\mathrm{PO}_{4}\right)_{6} \mathrm{~F}_{2}$ increases the hardness and stability of tooth enamel in the chemically aggressive environment of the oral cavity and also normally is a part of the tooth enamel.

Synthetic hydroxylapatite and fluorapatite can be obtained in many ways: "solution", hydrothermal, solid phase [11]. Large quantities of $\mathrm{Ca}_{10}\left(\mathrm{PO}_{4}\right)_{6}(\mathrm{OH})_{2}$, namely, they are referred to in the industrial production of toothpaste, it is more expedient to obtain from solutions. But the use of nitrates for these purposes [12] leads to:

a) contamination of the final product;

b) the formation of significant amounts of waste in the form of chemically aggressive solutions;

c) production of ceramic materials with unsatisfactory properties (due to a number of changing factors, stable reproducibility of the results is difficult).

In connection with this, it is promising to obtain ecologically safe synthetic powders of the composition $\mathrm{Ca}_{10}\left(\mathrm{PO}_{4}\right)_{6}(\mathrm{OH})_{2} / \mathrm{Ca}_{10}\left(\mathrm{PO}_{4}\right)_{6} \mathrm{~F}_{2}$, intended for replacing $\mathrm{CaCO}_{3}, \mathrm{SiO}_{2}, \mathrm{TiO}_{2}$ and biogenic hydroxylapatite with "green chemistry".

The study of the action of materials on the mucous membranes is mandatory in the conduct of sanitary toxicological studies of chemicals, preparations and cosmetic materials. This has a certain significance in connection with the diverse nature of the local action of substances when used in various fields of medicine and cosmetology. It should be noted that toothpastes [13] fall between the categories of "remedies" and "cosmetology". For this reason, the requirements for compulsory animal testing are not required.

It is believed that the inside of the adult human tooth-

paste does not fall. Producers and write on the packaging: "do not swallow". However, children under the age of 6 still do not know how to spit the remnants of toothpaste, in connection with which the drug partially enters the child's body. In this connection, it seems reasonable to conduct a full complex of toxicological and hygienic tests of powders in vivo. 


\section{Purpose and tasks of the research}

The purpose of this work is to assess the potential for the use of environmentally friendly $\mathrm{Ca}_{10}\left(\mathrm{PO}_{4}\right)_{6}(\mathrm{OH})_{2}$ and $\mathrm{Ca}_{10}\left(\mathrm{PO}_{4}\right)_{6} \mathrm{~F}_{2}$ powders obtained by the "green chemistry" methods in dentifrices and as an abrasive filler for therapeutic toothpastes that restore mineral balance of tooth enamel and study of their properties.

\section{following tasks:}

To achieve this goal, it was necessary to solve the

Synthesize environmentally friendly nanosizefibrous powders of $\mathrm{Ca}_{10}\left(\mathrm{PO}_{4}\right)_{6}(\mathrm{OH})_{2}$ and $\mathrm{Ca}_{10}\left(\mathrm{PO}_{4}\right)_{6} \mathrm{~F}_{2}$, to investigate their microstructure and properties; determine the optimal content of components.

Carry out a full complex of toxicological and hygienic tests of the developed materials on warm-blooded animals and determine whether the obtained materials possess gonadotoxic, embryotoxic, cytotoxic, mutagenic, teratogenic effects when they enter the body and exert an irritating effect on the mucous membranes and skin.

\section{Experimental part}

The following reagents were used in the work: orthophosphoric acid $\mathrm{H}_{3} \mathrm{PO}_{4}, \mathrm{CaF}_{2}, \mathrm{Ca}(\mathrm{OH})_{2}$ grades of "chemically pure" and "analytically pure". $\mathrm{Ca}_{10}\left(\mathrm{PO}_{4}\right)_{6}(\mathrm{OH})_{2}$ was obtained from solutions of $\mathrm{Ca}(\mathrm{OH})_{2}$ and $\mathrm{H}_{3} \mathrm{PO}_{4}$ in distilled water by stirring them for 8 hours and holding for 170 hours at room temperature for aging,

ensuring that the ratio of $\mathrm{Ca}$ ions to phosphate ions in a solution of $\mathrm{n}\left(\mathrm{Ca}^{2+}\right) / \mathrm{m}\left(\mathrm{PO} 4^{3-}\right)=1.67$. The product was filtered, and the precipitate was dried at $80{ }^{\circ} \mathrm{C}$. To synthesize $\mathrm{Ca}_{10}\left(\mathrm{PO}_{4}\right)_{6} \mathrm{~F}_{2}, \mathrm{Ca}_{3}\left(\mathrm{PO}_{4}\right)_{2}$ was pre-synthesized (by three-firing pelletized mixtures at a temperature of $1150-1250{ }^{\circ} \mathrm{C}$ with a holding time of 2 hours and intermediate grinding with a multistage temperature rise at a rate of $120-150{ }^{\circ} \mathrm{C}$ per hour). Fluorapatite $\mathrm{Ca}_{10}\left(\mathrm{PO}_{4}\right)_{6} \mathrm{~F}_{2}$ was synthesized from $\mathrm{CaF}_{2}$ and $\mathrm{Ca}_{3}\left(\mathrm{PO}_{4}\right)_{2}$ by roasting in the temperature range $1200-1250{ }^{\circ} \mathrm{C}$ with exposure for 3 hours followed by grinding. Then the obtained fluoroupathite was ground in a ball mill to particles of the required size. $\mathrm{Ca}_{10}\left(\mathrm{PO}_{4}\right)_{6} \mathrm{~F}_{2}$ can also be prepared by coprecipitation from solutions of $\mathrm{Ca}_{10}\left(\mathrm{NO}_{3}\right)_{2} \cdot 4 \mathrm{H}_{2} \mathrm{O}, \mathrm{NH}_{4} \mathrm{~F}$ and $\left(\mathrm{NH}_{4}\right)_{2} \mathrm{HPO}_{4}$, taken in the required stoichiometry, followed by heat treatment and grinding [14]. The firing was carried out in a chamber furnace in an air atmosphere in corundum crucibles. The temperature control was carried out with the help thermocouples PPR. To determine the optimum, different proportions of the components were selected.

According to the analysis, the nanocrystalline hydroxyapatite synthesized for use in skeletal surgery is a synthetic analogue of the mineral constituent of bone tissue. It is able to regulate the exchange of calcium and phosphorus in the body. Its main mineral is $\mathrm{Ca}_{10}\left(\mathrm{PO}_{4}\right)_{6}(\mathrm{OH})_{2}$, according to the chemical analysis the ratio of $\mathrm{Ca} / \mathrm{P}=1,67$. In its structure it is crystalline with a particle size in the nanometer range: from 25 to $50 \mathrm{~nm}$, with a degree of crystallinity of more than $96 \%$, a mass fraction of calcium of $40.82 \%$ and a mass fraction of phosphorus of $15.8 \%$. When heat treatment of powders (after aging), a more coarse-grained crystalline structure is formed, the particle size increases to $75-100 \mathrm{~nm}$.

X-ray phase analysis was carried out on a diffractometer on a DRON-2.0 unit using a standard procedure.

X-ray diffraction of samples of preparations showed that all reflections on $\mathrm{X}$-ray patterns correspond to pure $\mathrm{Ca}_{10}\left(\mathrm{PO}_{4}\right)_{6}(\mathrm{OH})_{2}$ and $\mathrm{Ca}_{10}\left(\mathrm{PO}_{4}\right)_{6}(\mathrm{OH})_{2} \mathrm{~F}_{2}$ which were identified by comparison with ASTM data. Chemical interaction between them does not occur and new chemical compounds do not appear. Synthesized hydroxyapatite and fluorapatite practically do not contain impurities of other calcium phosphates $\left(\mathrm{Ca}_{2} \mathrm{P}_{2} \mathrm{O}_{7}, \mathrm{Ca}_{3}\left(\mathrm{PO}_{4}\right)_{2}\right.$ etc. $)$, as well as heavy metals.

The microstructure of the resulting materials during their synthesis was examined using a scanning electron microscope Carl Zeiss, Germany. Conducted electron diffraction studies have shown that the so-deposited socalled "amorphous" hydroxyapatite is not so. In the electron diffraction method, the wavelength of the radiation used is about 2 orders of magnitude smaller than that of X-rays, so electron diffraction makes it possible to identify the dispersed phases even when X-ray methods are powerless. And this happens in those cases when the substance under study is X-ray amorphous. Conducted electron diffraction studies indicate that the material consists of dispersed crystals with an imperfect structure. This is indicated by slightly diffuse diffraction rings. It should be noted that in general the nature of the electron diffraction patterns is retained in the preparations after 3, 5 and 7 days of "aging". There is a pronounced tendency to the formation of more precise diffraction rings with increasing aging time, which indicates a certain process of ordering of the structure. After drying at $80^{\circ} \mathrm{C}$, dot reflexes appear in the early solid rings of the electron diffraction patterns. This indicates an increase in crystal size. Point patterns on the electronogram, which represent an enlarged image of the plane of the reciprocal lattice, are obtained from single-crystal samples. The calculation of the obtained electron diffraction patterns gives results that allow uniquely identifying hydroxyapatite. The investigated amorphous hydroxyapatite due to its very developed surface is in very active form. This is evidenced by the ratio of this material to the effects of electron radiation. The process of crystallization of this material is well traced: as a result of the action of the electron beam and an increase in the current density of the beam, spontaneous crystallization begins, which in electron micrographs is manifested in the form of condensation and fusion of the finest plates. After this, acute point reflexes appear on the microelectronogram of this region.

A significant influence of the synthesis temperature, the concentration of the initial substances, the $\mathrm{pH}$ of the solution, the duration of the process, the order and rate of mixing, the aging time on the morphology (from needle to spherical) of the crystallizing powder particles is established. This makes it possible to synthesize powders 
with a given specific surface, size and agglomeration of the crystals, morphology, and stoichiometry. Adjusting the particle size of the filler provides the possibility of obtaining the final product (toothpaste) of ordinary or increased abrasiveness. So when using powders with particles of a nanoscale range (from $50 \mathrm{~nm}$ ) and a degree of crystallinity of more than $96 \%$, their abrasivity will be in the lower and middle range of values. When the size of the powder particles from the nanoscale range comes out, the abrasivity of the final material will approach the maximum values.

The developed materials passed a full complex of toxicological and hygienic tests on warm-blooded animals. A preliminary assessment of the degree of toxicity of the studied materials was carried out on transplantable cell cultures of the He-2 and Vero line according to Wesley D. [15], as well as using human live cells (buccal cells) to change the bioelectrical potential of the cell nucleus by $\mathrm{V}$. G. Shakhbazov. [16].

The quantitative side of oxidation-reduction processes when introducing the developed powders was judged from the dynamics of activity of the enzymes of the experimental animals. The activity of enzymes was determined by conventional methods using a Specord twobeam spectrofluorimeter (Germany).

Many substances can lead to the accumulation of toxic products. Molecules of fatty acids and one of the final products, malonic dialdehyde, were determined as intermediate products of lipid peroxidation.

The study of lipid peroxidation by means of biochemiluminescence was performed on a medical biochemiluminometer BHLMC-1 both in dynamics and at the end of subacute experience. Super-weak luminescence was recorded in the blood and urine of white rats.

Changes in the content of microelements in organs and tissues with the introduction of the developed materials were determined by the atomic absorption method on a Saturn-1 spectrophotometer. The content of $\mathrm{Ca}, \mathrm{P}, \mathrm{F}, \mathrm{Mg}$, $\mathrm{Cu}$ was studied. $\mathrm{Zn}, \mathrm{Fe}, \mathrm{K}, \mathrm{Na}$ in the blood, liver, kidneys, heart, spleen, brain and adrenal glands of experimental animals.

Many chemical mutagens are capable of interfering with the synthesis of protein, RNA and DNA. The study of the effect of the materials studied on these processes was carried out on the cells of a Vero culture (a renal epithelium of a green monkey).

It was found that the synthesized materials refer to low-toxic, low-risk substances with poorly expressed cumulative properties. They do not possess skin-resorptive properties and do not irritate the skin and mucous membranes, nor do they have gonadotoxic, embryotoxic, cytotoxic, mutagenic and teratogenic effects.

The conducted researches show that the synthesized crystalline powders of apatite composition can be used both as abrasive components in toothpastes, including children's ones, and as basic inorganic fillers of means for healing tooth enamel detections, replenishing the deficiency of $\mathrm{Ca}$ and $\mathrm{P}$ in it, or restoring structures of the gingival mucosa. They not only do not have toxic effects on the body, but they are not (in contrast to $\mathrm{TiO}_{2}$ or $\mathrm{SiO}_{2}$ ) foreign to it, as they themselves, and the products of their decomposition are always present in the body. This will allow the production of new generation toothpastes and a higher level of cleaning and protection of tooth enamel among the population that will use it.

\section{Conclusions}

Eco-friendly powders of $\mathrm{Ca}_{10}\left(\mathrm{PO}_{4}\right)_{6}(\mathrm{OH})_{2}$ and $\mathrm{Ca}_{10}\left(\mathrm{PO}_{4}\right)_{6} \mathrm{~F}_{2}$ were obtained using the classical "solution" method of "green chemistry" using chemically pure reagents.

It was found that the administration of 3 to $7 \%$ $\mathrm{Ca}_{10}\left(\mathrm{PO}_{4}\right)_{6} \mathrm{~F}_{2}$ improves the stability of the material in contact with the chemically aggressive environment of the body (due to $\mathrm{F}^{-}$ions). The optimal content of fluorapatite in powder $(5,5$ mass. \%) was determined.

A full complex of toxicological and hygienic tests of the developed materials on warm-blooded animals was carried out. It is established that they belong to low-toxic, low-risk substances with slightly pronounced cumulative properties. They do not possess gonadotoxic, embryotoxic cytotoxic, mutagenic and teratogenic effects, they do not irritate mucous membranes and skin, nor do they possess skin-resorptive properties. The developed materials are potentially promising for use as abrasive-polishing components of toothpastes, including children's ones, as the main inorganic fillers for the healing of tooth enamel detectors, for the deficiency of $\mathrm{Ca}$ and $\mathrm{P}$ in it, or for restoring the structure of the gingival mucosa.

\section{References (transliterated)}

1. Freitas, R. A. Jr. Nanotechnology: nano medicine and nanosurgery. Int. J. Surg., 2005, Vol. 3, No 4, 243-246, doi: 10,1016/j.ijsu.2005.10.007.

2. Chekman, I. S., Malanchuk, V. A., Gordeychuk, M. A. Nanotahnologiyi i nanomaterialy: primeneniye $\mathrm{v}$ stomatologiyi i chelustno-litzevoy hirurgiyi [Nanotechnology and nanomaterials: application in dentistry and maxillofacial surgery]. Ukr. Med. journal, 2009, No 6 (64), 95-97.

3. Chen, X. Nanosilver: a nanoproduct in medical application. Toxicol. Lett., 2008, Vol. 176, No 1, 1 - 12, doi: 10,1016/j.toxlet.2007.10.004.

4. Webster, T. Nanomedicine. USA, Woodhead Publ., 2012, 704.

5. Joiner, A., Schwarz, A., Philpotts, C. J., Cox, T. F., Huber, K., Hannig, M. The protective nature of pellicle towards toothpaste abrasion on enamel and dentine. J. of Dentistry, 2008, Vol. 36, No 5, 360-368, doi: 10.1016/j.jdent.2008.01.010.

6. González-Cabezas, C., Hara, A. T., Hefferren, J., et al. Abrasivity testing of dentifrices - challenges and current state of the art. Monogr Oral Sci., 2013, No 23, 100-107, doi: $10.1159 / 000350476$.

7. Pickles, M. J., Joiner, A., Weader, E., Cooper, Y. L., Cox, T. F. Abrasion of human enamel and dentine caused by toothpastes of differing abrasivity determined using an in situ wear model. International Dental Journal, 2005, Vol. 55, No 3(1), 188-193, doi: 10.1111 / j.1875-595X.2005.tb00058.x. 
8. GOST 7983-99. Pasty zubnye. Obshie tehnicheskie usloviya [Toothpastes. General specifications]. - Moscow, Publishing Standarinform Publ., 2000, 36.

9. ISO 11609:2017(en), Dentistry - Dentifrices - Requirements, test methods and marking. Available at: https://www.iso.org/ standard/70956.html (accessed 10.05.2018).

10. Marcovic, L., Jordan, R. A., Glasser, M. C., Arnold, W.H., Rebel, J., Tillman, W., Ostermann, T., Zimmer, S. Effects of bleaching agents on surface roughness of filling materials. Dental Materials Journal, 2014, Vol. 33, No (1), 59-63, doi: 10.5005 / jp-journalals-10015-1437.

11. Barinov, S. M., Komlev, V. S. Biokeramika na osnove fosfatov kal'tsiya [Calcium phosphate based bioceramics] Moscow, Nauka Publ., 2005, 204.

12. Kovaleva, E. S., Philippov, Ya. Yu., Putlyaev, V. I., Tretyakov, Yu. D., Ivanov, V. K., Silkin, N. I., Galiullina, L.F., Rodionov, A. A., Mamin, G. V., Orlinskii, S. B., Salakhov, M. Kh. Biorezorbiruemyie poroshkovyie materialyi na osnove $\mathrm{Ca}_{10-\mathrm{x}} \mathrm{Na}_{\mathrm{x}}\left(\mathrm{PO}_{4}\right)_{6-\mathrm{x}}\left(\mathrm{CO}_{3}\right)_{\mathrm{x}}(\mathrm{OH})_{2}$ [Bioresorbable powdered materials based on $\mathrm{Ca}_{10}$ $\left.{ }_{x} \mathrm{Na}_{\mathrm{x}}\left(\mathrm{PO}_{4}\right)_{6-\mathrm{x}} \cdot\left(\mathrm{CO}_{3}\right)_{\mathrm{x}}(\mathrm{OH})_{2}\right]$. Scientists note the Kazan University. Series: Natural Sciences. - Kazan. univers. Publ., 2010, Vol. 152, 1, 80-98.

13. DSTU 2472:2006. Produkciya parfumerno-kosmetichna [State Standard 2472-2006. Production perfumery and cosmetics]. Kiev, Derzhspozhyvstandard Ukrayiny Publ., 2007, 71.

14. Sayenko, V. A., Shkuropatenko, V. A., Tarasov, R. V., Savina, S. A., Ulybkina, K. A., Belkin, F. V., Kolesnikov, D. A., Kovaleva, M. G. Poluchenie ftorapatita osazhdeniem $i z$ vodnyh rastvorov [Receipt fluorapatite by the method of the chemical besieging of water solutions]. Visnuk NTU "KhPI" [Bulletin of the National Technical University "KhPI"] Kharkov, NTU "KhPI" Publ., 2014, No 28 (1071), 117-127.

15. Gerald, D. Wasley. Animal Tissue Culture: Advances in Technique. London, Butterworth, 1972, 192 p. Rus. ed: Gerald D. Wasley. Novye metody kul'tury zhivotnykh tkaney. Moscow, Mir Publ., 1976, 255.

16. Shahbazov, V. Bioelektricheskie svojstva kletok: yadra, yadryshka i hromatina funkcionalnoj aktivnosti yadernogo genoma [Bioelectric properties of cells: nucleus, nucleus and chromatin of functional activity of the nuclear genome]. // Tez. dokladov I Vses. Biofiz. Syezda. T. 2 [Abstracts of the I Biofiz. Congress, T. 2]. Moscow, Moscow University Publ., 1982, 826 - 828. and chromatin of functional activity of the nuclear genome]. // Tez. dokladov I Vses. Biofiz. Syezda. T. 2 [Abstracts of the I Biofiz. Congress, T. 2]. Moscow, Moscow University Publ., 1982, 826-828.

\section{Список літератури}

1. Freitas, R. A. Jr. Nanotechnology: nanomedicine and nanosurgery / R. A. Jr. Freitas // Int. J. Surg. - 2005. Vol. 3, No 4. - P. 243 - 246. - doi: 10.1016/ j.ijsu.2005.10.007.

2. Чекман, И. С. Нанотехнологии и наноматериалы: применение в стоматологии и челюстно-лицевой хирургии / И. С. Чекман, В. А. Маланчук, М. А.
Гордейчук // Украӥнський медичний Журнал. - 2009. № 6 (74). - C. 95 - 97 .

3. Chen, $\mathbf{X}$. Nanosilver: a nanoproduct in medical application / X. Chen // Toxicol. Lett. - 2008. - Vol. 176, No 1. - P. 112. - doi: 10,1016/j.toxlet.2007.10.004.

4. Webster, T. Nanomedicine / T. Websterter. - USA: Woodhead Publ., 2012, 704 p.

5. Joiner, A. The protective nature of pellicle towards toothpaste abrasion on enamel and dentine / A. Joiner, A. Schwarz, C. J. Philpotts, T. F. Cox, K. Huber, M.Hannig // J. of Dentistry. - 2008. - Vol. 36, No 5. - P. 360 - 368. - doi: 10.1016/j.jdent.2008.01.010.

6. González-Cabezas, C. Abrasivity testing of dentifrices challenges and current state of the art / C. GonzálezCabezas, A. T. Hara, J. Hefferren // Monogr Oral Sci. 2013. - No 23. - P. 100 - 107. - doi: 10.1159/000350476.

7. Pickles, M. J. Abrasion of human enamel and dentine caused by toothpastes of differing abrasivity determined using an in situ wear model / M. J. Pickles, A. Joiner, E. Weader, Y. L. Cooper, T. F. Cox // International Dental Journal. - 2005. - Vol. 55, No 3 (1). - P. 188 - 193. - doi: 10.1111 / j.1875-595X.2005.tb00058.x.

8. ГОСТ 7983-99. Пасты зубные. Общие технические условия. - М.: Издательство стандартов, 2000. - 36 с.

9. ISO 11609:2017(en), Dentistry - Dentifrices Requirements, test methods and marking. URL: https: //www.iso.org/standard/70956.html (accessed 10.05.2018).

10. Marcovic, L. Effects of bleaching agents on surface roughness of filling materials / L. Marcovic, R. A. Jordan, M. C. Glasser, W. H. Arnold, J. Rebel, W. Tillman, T. Ostermann, S. Zimmer // Dental Materials Journal. 2014. - Vol. 33, No (1). - P. 59 - 63. - doi: 10.5005 / jpjournalals-10015-1437.

11. Баринов, С. М. Биокерамика на основе фосфатов кальция / С. М. Баринов, В.С. Комлев. - М.: Наука, 2005. $-204 \mathrm{c}$

12. Ковалева, Е. С. Биорезорбируемые порошковые материалы на основе $\mathrm{Ca}_{10-\mathrm{x}} \mathrm{Na}_{\mathrm{x}}\left(\mathrm{PO}_{4}\right)_{6-\mathrm{x}}\left(\mathrm{CO}_{3}\right)_{\mathrm{x}}(\mathrm{OH})_{2} /[E$. С. Ковалева, Я. Ю. Филиппов, В. И. Путляев, Ю. Д. Третьяков и др. ] // Ученые записки Казанского ун-та. Серия: Естественные науки. - 2010. - Т. 152, № 1. - С. $80-98$.

13. ДСТУ 2472-2006. Продукція парфумерно-косметична. - К.: Держспоживстандарт України, 2007. - 71 с.

14. Саенко, С. Ю. Получение фторапатита осаждением из водных растворов / [C. Ю. Саенко, В. А. Шкуропатенко, Р. В. Тарасов и др.] // Вісник НТУ «ХПІ». Серія: Хімія, хімічна технологія та екологія. 2014. - № 28 (1071). - С. 117 - 127.

15. Уосли, Д. Новые методы культуры животных тканей / Джорж Уосли. - М.: Мир, 1976. - 255 с.

16. Шахбазов, В. Г. Биоэлектрические свойства клеток: ядра, ядрышка и хроматина функциональной активности ядерного генома / В. Г. Шахбазов // Тез. докладов І Всес. Биофиз. Съезда. - Том 2. - М.: Изд-во МГУ, 1982. - С. $826-828$.

\section{Сведения об авторах (About authors)}

Кривільова Світлана Павлівна - кандидат технічних наук, доцент, Національний технічний університет «Харківський политехнічний інститут», доцент кафедры хімічної техніки і промислової екології, м. Харків, Україна; e-mail: spkri@ukr.net.

Svetlana Krivileva - Candidate of Technical Sciences (Ph. D.), Docent, Associate Professor of Department of "Chemical Technics and Industrial Ecology", National Technical University "Kharkiv Polytechnic Institute", Kharkiv, Ukraine; e-mail: spkri@ukr.net. 
Please cite this article as:

Krivileva, S. Evaluation of the possibility of using nanocrystalline apatite powders as inorganic fillers of toothpastes. Bulletin of NTU "KhPI". Series: New solutions in modern technologies. - Kharkiv: NTU"KhPI", 2018, 16(1292), 158-164, doi:10.20998/24134295.2018.16.24

Будь ласка, посилайтесь на изю статтю наступним чином:

Кривільова, С. П. Оцінка можливості використання нанокристалічних порошків апатитового складу в якості неорганічних наповнювачів зубних паст / С. П. Кривільова // Вісник НТУ «ХПI», Серія: Нові рішення в сучасних технологіях. - Харків: НТУ «ХПІ». - 2018. - № 16 (1292). - С. 158-164. - doi:10.20998/2413-4295.2018.16.24.

Пожалуйста, ссылайтесь на эту статью следующим образом:

Кривилёва, С. П. Оценка возможности использования нанокристаллических порошков апатитного состава в качестве неор- ганических наполнителей зубных паст / С. П. Кривилёва // Вестник НТУ «ХПИ», Серия: Новые решения в современных технологиях. - Харьков: НТУ «ХПИ». - 2018. - № 16 (1292). - С. 158-164. - doi:10.20998/2413-4295.2018.16.24.

АННОТАЦИЯ В статье рассмотрены наиболее распространённые виды зубных паст и материалы, используемые 6 качестве неорганических абразивно-полирующих наполнителей лечебных зубных пастах, существующих на рынке. Оиенена перспективность использования в составе лечебных зубных паст и средств по уходу за зубами и полостью рта порошков на основе гидроксилапатита. Показано, что в имеющихся на рынке продуктах применяется биогенный гидроксилапатит, представленный либо в неактивной форме, либо содержащий депротеинизированные кости рыб или сельскохозяйственных животных (свиней или крупного рогатого скота). Показана перспективность применения синтетических нанокристаллических порошков апатитного состава, иеленаправленно разработанных для пластики дефектов скелета, 6 составе зубных паст и в продуктах по уходу за зубами - для замены неорганических компонентов в их составе, состоящих из мела, каолина, соды (в нижнем иеновом сегменте), диоксида титана или аэросила (в верхнем ценовом диапазоне), или биогенного гидроксилапатита (в составе инновационных продуктов премиум-класса), традиционно используемых в качестве абразивных составляющих. Показано что экологически чистые (не содержащие тяжелых металлов и ингредиентов животного происхождения) синтетические нанокристаллические порошки Са1о $\left.(\mathrm{PO})_{6}\right)_{(\mathrm{OH})}{ }_{2}$ могут быть получены методами «зеленой химии» из растворов Са $(\mathrm{OH})_{2}$ и $\mathrm{H}_{3}\left(\mathrm{PO}_{4}\right)_{2}$, а Са $\mathrm{Ca}_{10}\left(\mathrm{PO}_{4}\right)_{6} \mathrm{~F}_{2}$ - твердой фазе или соосаждением из растворов Сало $\left(\mathrm{NO}_{3}\right)_{2} \cdot 4 \mathrm{H}_{2} \mathrm{O}, \mathrm{NH}_{4} \mathrm{~F}$ и $\left(\mathrm{NH}_{4}\right)_{2} \mathrm{HPO}_{4}$, взятых в необходимой стехиометрии, с последующей термообработкой $и$ измельчением. Определены оптимальные соотношения исходных компонентов и режимы термообработки, обеспечивающие получение порошка $\mathrm{Ca}_{10}\left(\mathrm{PO}_{4}\right)_{6}(\mathrm{OH})_{2}$ с соотношением $\mathrm{Ca} / \mathrm{P}=1,67$, и Сало $\left(\mathrm{PO}_{4}\right)_{6} \mathrm{~F}_{2}$ высокой чистоты, размеры кристаллов которых соответствуют наноразмерному диапазону. При проведении полного комплекса токсиколого-гигиенических испытаний in vivo установлено, что полученный материал относится к малотоксичным, малоопасным веществам со слабо выраженными кумулятивными свойствами; он не оказывает раздражающего действия на слизистые оболочки и не обладает гонадодотоксическим, эмбритоксическим, ичитотоксическим, мутагенным, тератогенным эффектами при попадании внутрь организма, что делает безопасным и потенциально перспективным его использование в качестве неорганического наполнителя зубных паст и средств для залечивания детектов зубной эмали, восполнения дефицита Са и $P$ в ней и восстановления структуры слизистой оболочки десен.

Ключевые слова: лечебные зубные пасты; средства по уходу за зубами; абразивно-полирующие наполнители; гидроксилапатит; диоксид титана. 